British science politics

\section{Better prospects at polls?}

THi: mechanics of transferring the results of scientific research, principally defence work, from the laboratory to the shop floor has become a political issue in Britain and could soon result in the axing of some projects.

The government will publish next month the results of a major study of public support for scientific research, while the Labour party, the principal opposition party, has promised that, if it wins the next general election, it will create a Ministry of Science to ensure the better exploitation of research.

The new study, which has taken about a year to complete, is an attempt by the government to assess whether it is "getting value for money" and a satisfactory return on the $£ 4,600$ million now invested each year in research and development.

The government has long been convinced that there is an inadequate bridge between the research institutes and the commercial sector. The review, supervised by an unnamed cabinet minister, has received advice from the new watchdog on government supported research, the Science and Technology Assessment Office, a unit within the Cabinet Office.

The study, covering all government department's spending on research and development, is likely to recommend a reallocation of resources; changes are likely, in particular, at the Ministry of Defence and the Department of Education and Science.

The Labour party last week confirmed its intention to create a new ministry, "manned by people who understand science", to ensure the commercial exploitation of the findings of governmentsupported research; to that end, the ministry would have the power to breach traditional departmental boundaries.

The third major political party in Britain, the Social Democratic Party Liberal Alliance, is equally dissatisfied with technology transfer from academic institutions and government-supported research programmes to the assembly line. Its approach would be to create a structure outside government departments with a $£ 200$ million launch budget and simultaneously to increase support for research by about $£ 40$ million a year.

The Alliance policy endorses the view held by the other two parties. Its policy document says that although government must provide the framework within which industry may develop in a competitive environment, the needs of the new technologies are so urgent that Britain "cannot wait for the invisible hand of the market to take effect"

Bill Johnstone

\title{
Soviet Union
}

\section{New president for academy}

ThF Soviet Academy of Sciences has a new president, an appointment that seems to conform to Mr Gorbachev's policy of breaking down inter-ministerial barriers in science and technology. Academician Gurii Marchuk, former director of the Siberian branch of the Academy of Sciences of the USSR (1975-80) and more recently head of the State Committee for Science and Techrology (1980-85), was last week unanimously elected to the office relinquished by the 83-year-old Anatolii Aleksandrov who is said to have retired "at his own request". Marchuk was elected by secret ballot, but as with Aleksandrov, and unlike earlier presidents, the proposing speech was made not by a scientist, but by Politburo Member and Central Committee Secretary Yurii Ligachev.

Marchuk carries on the tradition of the past several decades, which have entrusted the leadership of the academy to mathematicians or physicists. The previous two presidents (excluding the caretaker president Vladimir Kotel'nikov) have been an expert in rocket technology (Mstislav Keldysh) and a nuclear physicist (Anatolii Aleksandrov), whose appointments largely coincided with the prevailing priority in Soviet research when they were elected.

On that basis, it would be difficult to identify the current Soviet priority, for Marchuk is an all-rounder. After graduating from Leningrad University, he became a professor of mathematics, specializing in the dynamics of large-scale atmospheric processes, and then a researcher at the Geophysics Institute of the Academy of Sciences. He then moved on to nuclear power engineering, and then to computer technology, founding the Computer Centre of the Siberian Branch of the Academy of Sciences. Members of the academy last week paid tribute to his democratic outlook and flexibility as an administrator, and noted that during his time at the Siberian Branch of the academy, virtually all discoveries made there were implemented in Soviet industry. According to Boris Paton, president of the Ukrainian Academy of Sciences, Marchuk "shows an equally good knowledge of fundamental science and industry".

But in proposing Marchuk for the presidency, Ligachev did not confine himself to eulogy of his candidate. He used the occasion to castigate the academy for a loss of initiative in the long-term planning of promising fields of science, and for paying insufficient attention to "general state programmes". This system, Ligachev warned, can and must be rectified.

The Central Committee of the Communist Party of the Soviet Union is pre- pared, he noted, to consider the problems of development of the academy, to define measures to resolve pressing questions, and, in particular, to look at research teams that are not sufficiently productive. The role of regional branches of the allUnion academy and the fourteen academies of the union republics must be improved, said Ligachev, to improve the "labour efficiency" of every research team in the country.

Replying to these criticisms on behalf of the all-Union academy and its unionrepublic associates, Marchuk repeated Ligachev's calls for efficiency, and called on all scientists to rethink the role of science at this particular stage of Soviet development. He called for the branches of the academy to be transformed into "headquarters which elaborate the strategy of science and determine scientific priorities and the direction of research" and, in particular, pledged his support $\mathrm{Mr}$ Gorbachev's science policy. Vera Rich

\section{Mars spacecraft}

If the satellite picture looks more like a communications satellite than a planetary probe, that is not surprising. Last month, the National Aeronautics and Space Administration (NASA) signed a contract with RCA Astro-Electronics Division to build the Mars Observer spacecraft, the first of what could be a series of relatively low cost planetary missions drawing heavily on existing satellite technology. The Mars Observer structure is based on

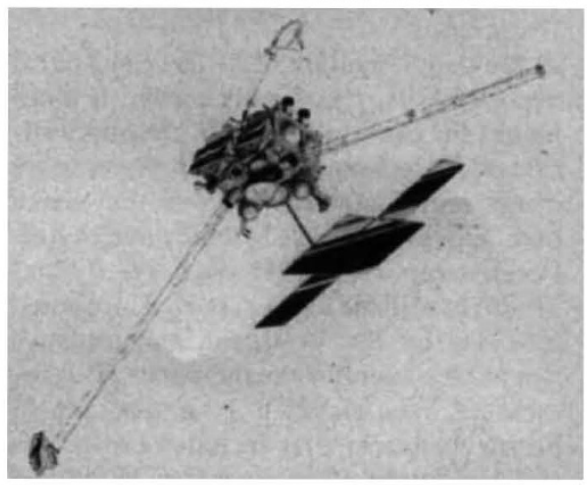

RCA's Satcom communication satellite. The spacecraft will carry eight instruments to study the magnetic and gravitational fields, the physical characteristics of surface material, and the atmosphere and seasonal changes of Mars. Project manager William Purdy says the point of the observer series is to spend "more money on the science than on the spacecraft". The budget for the mission is approximately $\$ 252$ million, and the spacecraft costs about $\$ \mathbf{5 0}$ million. No specific launch date has been set, but 1990 is the target. 